\title{
PENGEMBANGAN KOMIK BERBASIS SCIENCE EDUTAINMENT TERHADAP SIKAP LITERASI PESERTA DIDIK
}

\section{Pradana Meisandy Trisdianto ${ }^{1}$, Muriani Nur Hayati ${ }^{2}$, Bayu Widiyanto ${ }^{3}$}

\author{
Pendidikan IPA Universitas Pancasakti Tegal \\ *corresponding Author : pradanaaja796@gmail.com
}

DOI: 10.24929/lensa.v10i2.109

\begin{abstract}
ABSTRAK
Penelitian bertujuan untuk mengetahui tahapan pengembangan komik berbasis Science Edutainment dan untuk mengetahui efektivitas implementasi komik berbasis Science Edutainment terhadap sikap literasi sains peserta didik. Penelitian ini menggunakan penelitian pengembangan (Reseaerch and Development) dengan model 4 D. Subjek penelitian ini adalah peserta didik kelas VII MTs Asy-Syafi'iyyah Jatibarang. Hasil penelitian menunjukkan bahwa pengembangan komik meliputi 4 tahap pengembangan yaitu; 1) tahap pendefinisian, 2) tahap perancangan, 3) tahap pengembangan, 4) tahap penyebarluasan meliputi uji skala kecil kepada 7 peserta didik dan uji skala besar kepada 32 peserta didik kelas VII MTs Asy-Syafi'iyyah Jatibarang. Hasil uji skala kecil memperoleh rata-rata skor 33,71, dan uji skala besar memperoleh rata-rata skor 33,6, Sehingga menunjukkan bahwa komik berbasis Science Edutainment sangat layak untuk digunakan sebagai media pembelajaran. Hasil N-Gain Score pada bidang minat sains sebesar 0,52 yang termasuk kriteria sedang. Hasil N-Gain Score pada bidang menilai pendekatan ilmiah sebesar 0,51 yang termasuk kriteria sedang. Hasil N-Gain Score pada bidang kesadaran lingkungan sebesar 0,59 yang termasuk kriteria sedang. Hasil tersebut menunjukkan bahwa penerapan media komik berbasis Science Edutainment yang dilakukan sudah cukup efektif sehingga dapat meningkatkan kemampuan literasi sains peserta didik pada aspek sikap.
\end{abstract}

Kata kunci: Komik, Science Edutainment, Aspek Sikap Literasi Sains

\section{ABSTRACT}

This study aims to determine the stages of the development of Science Edutainmentbased comics and to determine the effectiveness of the implementation of Science Edutainment-based comics on students' scientific literacy attitudes. This research used research and development (Research and Development) with a $4 \mathrm{D}$ model. The subjects of this study were students of class VII MTs Asy-Syafi'iyyah Jatibarang. The results showed that the development of comics includes 4 stages of development, namely; 1) the defining stage, 2) the design stage, 3) the development stage, 4) the dissemination stage including a small-scale test for 7 students and a large-scale test for 32 students of class VII MTs Asy-Syafi'iyyah Jatibarang. The results of the smallscale test obtained an average score of 33.71, and the large-scale test obtained an average score of 33.6, so that it shows that Science Edutainment-based comics are very feasible to be used as a learning medium. The result of the $N$-Gain Score in the field of interest in science is 0.52 which is included in the moderate criteria. The results of the $\mathrm{N}$-Gain Score in the field of assessing the scientific approach are 0.51 which is included in the moderate criteria. The results of the $\mathrm{N}$-Gain Score in the area of environmental awareness are 0.59 which is included in the moderate criteria. These results indicate that the application of Science Edutainment-based comic media has 
been effective enough to increase students' scientific literacy skills in the attitude aspect.

Keywords: Development of learning tools, Natural Science, Character, Problem based learning, Science process skills

\section{PENDAHULUAN}

Data pencapaian literasi sains peserta didik Indonesia menurut PISA masih tergolong rendah yang menjadi salah satu faktor permasalahan pendidikan di Indonesia. Menurut hasil PISA 2015 menyatakan bahwa kemampuan literasi sains anak Indonesia memiliki perolehan skor sebesar 403 yang berada di peringkat ke-64 dari 72 negara.

Menurut Organization for Economic Cooperation and Development (OECD) 2016, bahwa skor literasi sains masuk dalam kategori kecakapan level 1 dengan rentang skor $335 \leq 409$ poin. Pada kecakapan level 1 ini, peserta didik hanya mempunyai pengetahuan sains yang terbatas dan hanya bisa diterapkan pada beberapa kondisi saja. Contohnya seperti memberikan penjelasan ilmiah yang mudah dan mengikuti bukti-bukti eksplisit.

Berdasarkan hasil PISA, bahwa kemampuan literasi peserta didik di Indonesia tergolong rendah, salah satunya yaitu literasi bahasa (Kharizmi, 2015). Menurut Zhasda \& Sumarmin (2018) bahwa kebiasaan peserta didik akan mempengaruhi hasil literasi sains peserta didik. Salah satu contohnya yaitu seperti malas membaca dan lebih suka menghafal materi pelajaran yang akan diujikan saja. Hal tersebut akan berdampak pada peserta didik yang akan mengalami kesulitan untuk memahami materi. Sehingga ilmu yang diperoleh tidak bisa diterapkan dalam kehidupan mereka.

Menurut Widodo (2014), bahwa ada beberapa hal yang harus diperhatikan dalam kemampuan literasi sains yaitu karakteristik dan potensi peserta didik, pengembangan bahan ajar yang sesuai, menyusun instrumen yang tepat, dan pengelolaan kegiatan pembelajaran yang baik. Hal-hal tersebut harus diperhatikan agar kemampuan literasi sains yang rendah dapat ditingkatkan. Menurut Pardimin \& Adi Widodo (2017), bahwa bagi peserta didik media pembelajaran menjadi faktor yang menentukan untuk berpartisipasi dalam proses belajar dan menciptakan minat belajar. Hal ini karena media pembelajaran berfungsi dalam penyampaian materi dari guru kepada peserta didik untuk mendorong proses belajar agar bisa merangsang pikiran, perasaan, keprihatinan, atau kemauan peserta didik. Pesan pembelajarannya yaitu materi pelajaran yang ingin disampaikan, dan terjadinya proses belajar merupakan tujuan yang ingin dicapai (Muhson, 2010).

Berdasarkan hasil studi pendahuluan di MTs Asy-Syafi'iyyah Jatibarang, bahwa metode ceramah, tanya jawab, dan pemberian tugas atau evaluasi proses pembelajaran adalah metode yang paling umum dilakukan guru. Sumber belajar yang digunakan dalam pembelajaran hanya berupa buku paket dan Lembar Kerja Peserta Didik (LKPD). Buku paket dan LKPD belum bisa meningkatkan motivasi belajar peserta didik. Peserta didik kurang menyukai materi yang hanya berupa tulisan yang panjang. Peserta didik lebih suka buku yang memiliki banyak gambar, warna karena lebih menarik untuk dibaca. Sehingga masih sulit menentukan media yang efektif untuk materi pencemaran lingkungan.

Proses pembelajaran IPA akan dipengaruhi oleh beberapa faktor. Faktor yang pertama yaitu masukkan peserta didik, yang kedua yaitu masukkan instrumental, kurikulum, guru, metode, media, dan faktor yang ketiga yaitu masukkan lingkungan sosial dan alamiah. Faktor-faktor tersebut akan berpengaruh terhadap keefektifan dalam proses pembelajaran IPA (Haryanti, Hayati, \& Fatkhurrohman, 2018). Keefektifan dalam proses pembelajaran IPA khususnya pada materi pencemaran lingkungan bisa disajikan dalam bentuk yang menarik. Peserta didik akan merasa senang dengan penyajian materi yang menarik dan dapat memunculkan minat belajar dalam diri peserta didik. Dengan begitu peserta didik akan mudah dalam memahami materi pembelajaran. Hal tersebut sesuai pendapat dari Hayati (2016) bahwa jika 
peserta didik berpartisipasi aktif maka proses pembelajaran akan lebih efektif. Penggunaan media pembelajaran akan mengakibatkan kondisi belajar yang menyenangkan. Pembelajaran akan lebih menarik, bermakna, berkesan, dan mudah dipahami oleh peserta didik jika menggunakan media pembelajaran. Dengan menggunakan media pembelajaran peserta didik dapat meningkatkan motivasi belajar, kreativitas, dan belajar berpikir tingkat tinggi sehingga dapa memacu pengembangan intelektual serta emosional peserta didik (Aisyah, Widiyanto, \& Fatkhurrohman, 2018).

Komik sangat berpotensi untuk dijadikan sebagai media pembelajaran karena komik populer di kalangan anak-anak maupun orang dewasa. Penyajian materi pembelajaran dalam bentuk komik dapat menjadikan penyajian materi tersebut lebih menarik dan disukai peserta didik. Dengan menggunakan komik, pembelajaran yang awalnya membosankan menjadi menyenangkan karena peserta didik lebih bisa memahami dan lebih termotivasi dalam meningkatkan prestasi belajar (Evelyn, 2015).

Media komik merupakan sumber belajar yang dapat membantu peserta didik dalam kegiatan pembelajaran. Media komik bisa digunakan sebagai alat bantu mengajar oleh guru dan sebagai media belajar pada peserta didik. berdasarkan observasi yang dilakukan bahwa penggunaan komik dalam pembelajaran sains masih jarang sekali digunakan. Sehingga dengan menggunakan komik diharapkan dapat membantu guru dalam proses pembelajaran yang lebih efektif dan efisien (Saputro A.D., 2015).

Menurut Daryanto (2015) bahwa peserta didik lebih suka buku yang memiliki banyak gambar, warna, dan ditayangkan dalam bentuk kartun. Motivasi peserta didik untuk belajar IPA akan berkurang jika minat peserta didik kurang sehingga akan berdampak pada hasil pembelajaran. Komik sains merupakan salah satu media untuk mengatasi permasalahan tersebut. Sudjana dan Rivai (2015) menyatakan komik adalah suatu bentuk kartun yang berisi karakter dan memerankan tokoh dalam urutan sebuah cerita. Maka dari itu pada penelitian kali ini akan mencoba menggunakan komik karena pada saat ini penggunaan komik sebagai media pembelajaran di jenjang sekolah menengah pertama masih sangat jarang sekali. Sehingga penelitian ini memiliki 2 tujuan yaitu :

1. Untuk mengetahui tahapan pengembangan komik berbasis Science Edutainment.

2. Untuk mengetahui efektivitas implementasi komik berbasis Science Edutainment terhadap sikap literasi sains peserta didik.

\section{METODE PENELITIAN}

Pada penelitian ini menggunakan jenis penelitian $R \& D$ (Research and Development) dengan model 4-D (Define, Design, Develop and Dissemination). Penelitian ini bertujuan untuk mengembangkan dan menghasilkan produk baru.

Model pengembangan perangkat 4-D bersumber pada penelitian Thiagarajan (1974). Pada Model 4-Dini meliputi 4 tahapan yaitu yang pertama Define atau pendefinisian, yang kedua ada Design atau perancangan, yang ketiga ada Develop atau pengembangan, dan yang terakhir ada Disseminate atau penyebarluasan. Namun karena adanya keterbatasan waktu dan biaya maka penelitian ini hanya sampai pada tahap develop atau pengembangan. Produk yang dikembangkan adalah sebuah komik berbasis Science Edutainment terhadap sikap literasi peserta didik. Prosedur penelitiannya akan dijelaskan di bawah ini.

1. Tahap Pendefinisian (define)

Tahap define dilakukan untuk mengetahui proses pembelajaran di Kelas VII di MTs Asy-Syafi'iyyah Jatibarang. Hal ini bertujuan agar produk yang digunakan sesuai atau tidak melenceng. Adapun tahap define yaitu :

a. Observasi Kelas

Kegiatan observasi kelas ini dilaksanakan ketika sedang berlangsungnya kegiatan belajar mengajar di kelas. Observasi kelas ini bertujuan untuk mengetahui perangkat pembelajaran, metode mengajar dan sikap peserta didik. Observasi dilakukan di kelas VII A di MTs Asy-Syafi'iyyah Jatibarang. 
b. Wawancara

Kegiatan wawancara ini dilakukan untuk mengetahui kebutuhan guru dan peserta didik, situasi saat pembelajaran dan bahan ajar yang dibutuhkan. Wawancara ini dilakukan dengan Ibu Dewi Rachmawati, S.Pd. selaku guru mata pelajaran Ilmu Pengetahuan Alam (IPA) di kelas VII A MTs Asy-Syafi'iyyah Jatibarang.

c. Studi Pustaka

- Mengkaji Kurikulum

Kegiatan ini dilakukan untuk menentukan materi dengan mempelajari silabus yang ada di MTs Asy-Syafi'iyyah Jatibarang agar pembelajaran sesuai dengan tujuan pembelajaran.

- Mengidentifikasi Materi yang Dibutuhkan Komik Berbasis Science Edutainment Kegiatan ini dilakukan dengan cara bertukar pendapat dengan guru mata pelajaran IImu Pengetahuan Alam (IPA).

\section{Tahap Design (Perancangan)}

Dalam tahap ini terdapat 2 langkah yaitu :

a. Rancangan Isi Komik Berbasis Science Edutainment

Langkah yang pertama dilakukan yaitu penyusunan kerangka komik sesuai kriteria yang baik. Kerangka komik meliputi sampul depan yang berisi judul dan gambar materi. Bagian pendahuluan (kata pengantar, standar kompetensi, kompetensi dasar, dan indikator). Bagian isi (berisi materi pembelajaran dan evaluasi). Bagian penutup (daftar pustaka dan profil penulis).

b. Rancangan Tampilan komik berbasis Science Edutainment

Tahap ini dilakukan untuk merancang tampilan sampul, warna, format pengetikan maupun jenis kertas yang akan digunakan.

\section{Tahap Develop (Pengembangan)}

Pada tahap ini terdapat proses uji Validasi, revisi, dan uji coba di lapangan dengan tujuan untuk menghasilkan produk akhir. Pada tahap pengembangan ini terdapat 2 langkah, yaitu :

a. Validasi Ahli

Ada 2 tahap validasi yaitu validasi dari ahli materi ( 1 guru IPA dan 1 dosen IPA) dan validasi dari ahli media (1 guru seni rupa). Tahap validasi ahli materi yaitu mengevaluasi komik berbasis Science Edutainment agar sesuai dengan materi Ilmu Pengetahuan Alam (IPA). Tahap validasi ahli media yaitu mengevaluasi komik berbasis Science Edutainment agar sesuai dengan kualitas dan kesesuaian tampilan.

b. Revisi

Saran dan komentar dari hasil validasi ahli materi dan validasi ahli media dijadikan sebagai bahan revisi.

c. Uji Coba Lapangan

Ada 2 uji coba lapangan yaitu uji coba skala kecil dan uji coba skala besar. Uji coba skala kecil dilakukan pada 7 peserta didik kelas VII A. Uji coba ini dilakukan untuk mendapat masukan dari peserta didik sebagai pengguna produk. Uji coba skala besar dilakukan pada 32 peserta didik. Uji coba ini untuk menentukan apakah komik tersebut sudah layak untuk dijadikan sebagai bahan ajar apa tidak. Uji coba skala besar dilakukan di kelas VII A MTs Asy-Syafi'iyyah Jatibarang karena adanya keterbatasan peneliti.

Teknik pengumpulan datanya dengan wawancara, observasi, kuesioner dan dokumentasi. Sehingga berikut ini merupakan analisis datanya :

1. Analisis Data Kuesioner Validasi Komik

Analisis data dari kuesioner uji Validasi para ahli dan uji coba di lapangan kepada responden yang digunakan untuk mengetahui kelayakan dan respons peserta didik terhadap komik yang dibuat.

$\bar{x}=\frac{\Sigma \mathrm{x}}{N}$

Keterangan : 
$\bar{x}=$ Skor rata-rata

$\Sigma \mathrm{x}=$ Skor total

$N=$ Jumlah butir Soal

Data hasil kuesioner validasi komik tersebut kemudian diubah menjadi data kualitatif berdasarkan kriteria penilaian ideal. Ketentuan konversi skor kriteria penilaian ditunjukkan pada tabel 1 .

Tabel 1. Konversi Skor Kriteria Penilaian

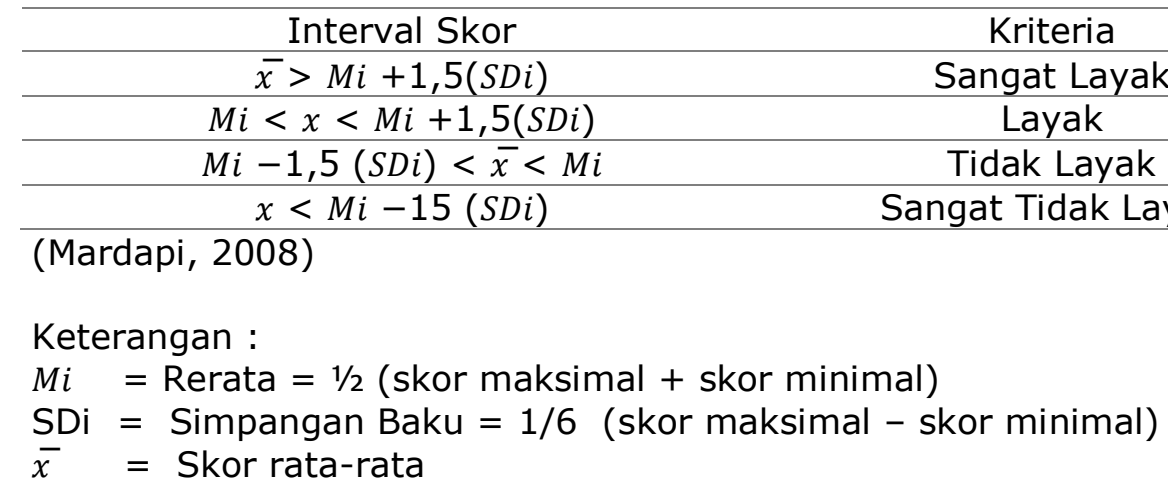

2. Analisis Data Kuesioner Sikap Literasi Sains

Analisis data yang diperoleh dari kuesioner sikap literasi sains dari responden (peserta didik) digunakan untuk mengetahui efektivitas implementasi komik terhadap sikap literasi sains peserta didik. Efektivitas implementasi komik terhadap sikap literasi sains di hitung dengan menggunakan nilai N-Gain Score.

$$
<\mathrm{g}>=\frac{\text { Spost }- \text { Spre }}{\text { Sm ideal }- \text { Spre }} \times 100 \%
$$

Keterangan :

$<\mathrm{g}>\quad=$ skor rata-rata gain yang dinormalisasi

Spost $\quad=$ skor rata-rata tes akhir peserta didik

Spre = skor rata-rata tes awal peserta didik

$\mathrm{Sm}$ ideal $=$ skor maksimum ideal yang diperoleh dari nilai rata-rata

Hasil $\mathrm{N}$-gain yang telah diperoleh kemudian diubah ke dalam data deskriptif sesuai kriteria pada tabel 2 .

Tabel 2. Interpretasi Skor Rata-Rata N-Gain

\begin{tabular}{cc}
\hline Nilai $\langle\mathrm{g}\rangle$ & Kriteria \\
\hline$<\mathrm{g}>\geq 0,7$ & Tinggi \\
\hline $0,3 \leq<\mathrm{g}><0,7$ & Sedang \\
\hline$<\mathrm{g}><0,3$ & Rendah \\
\hline
\end{tabular}

(Hake, 1999)

\section{HASIL DAN PEMBAHASAN}

\section{Hasil Validasi Produk}

Validasi produk meliputi validasi materi pada 2 validator ahli materi. Validasi media pada 1 validator ahli media. Hasil validasi ahli materi memperoleh skor ratarata sebesar 3,5. Rata-rata skor penilaian ahli materi yang diperoleh produk media komik yang dikembangkan tersebut termasuk dalam kriteria "sangat layak". Penilaian tersebut didasarkan pada isi materi/kualitas materi. Hasil uji validasi oleh ahli materi ditunjukkan pada Gambar 1. 


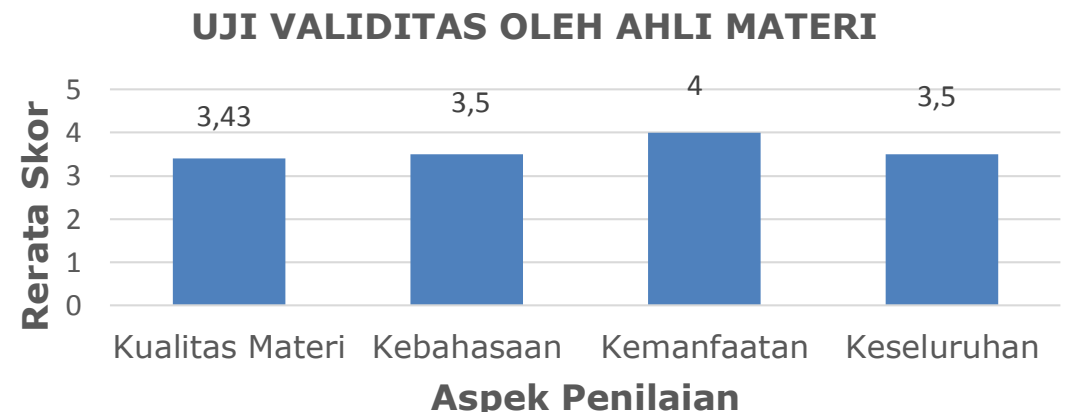

\section{Gambar 1. Hasil Uji Validasi Komik oleh Ahli Materi}

Setelah uji validasi komik pada ahli materi dan mendapatkan hasil yang valid. Selanjutnya yaitu uji validasi pada ahli media. Hasil perolehan skor rata-rata validasi ahli media yaitu sebesar 3,93 dengan kriteria "sangat layak". Penilaian ahli media dilakukan berdasarkan aspek penampilan fisik dan kemudahan penggunaan. Hasil uji validasi oleh ahli media ditunjukkan pada Gambar 2.

\section{UJI VALIDITAS OLEH AHLI MEDIA}

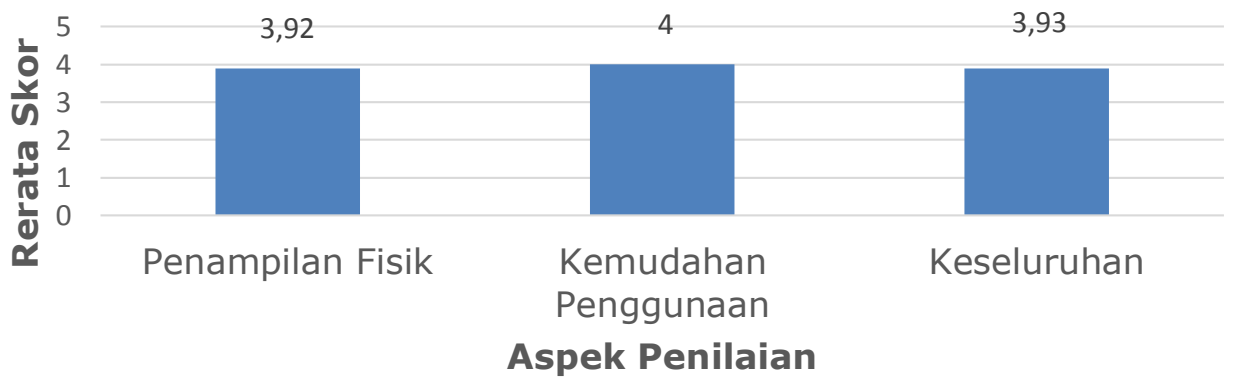

Gambar 2. Hasil Uji Validasi Komik oleh Ahli Media

Komik yang dikembangkan dikatakan layak apabila lolos tahap validasi, seperti pendapat Purwanto (2013) bahwa media komik yang dikembangkan dikatakan layak secara teoretis untuk digunakan pada pembelajaran dilihat dari hasil validasi pakar. Menurut pendapat Muhafid (2013) mengatakan bahwa setelah lolos tahap validasi produk pengembangannya layak untuk digunakan. Produk yang sudah lolos tahap validasi selanjutnya sudah bisa diujikan ke peserta didik.

\section{Hasil Uji Skala Kecil}

Hasil uji skala kecil produk pada 7 peserta didik diperoleh rata-rata skor sebesar 3,37 dengan kriteria sangat layak. Hal ini menunjukkan bahwa produk yang dikembangkan mendapatkan respons positif dari peserta didik. Hasil uji coba skala kecil ditunjukkan pada Gambar 3.

UJI SKALA KECIL PADA PESERTA DIDIK

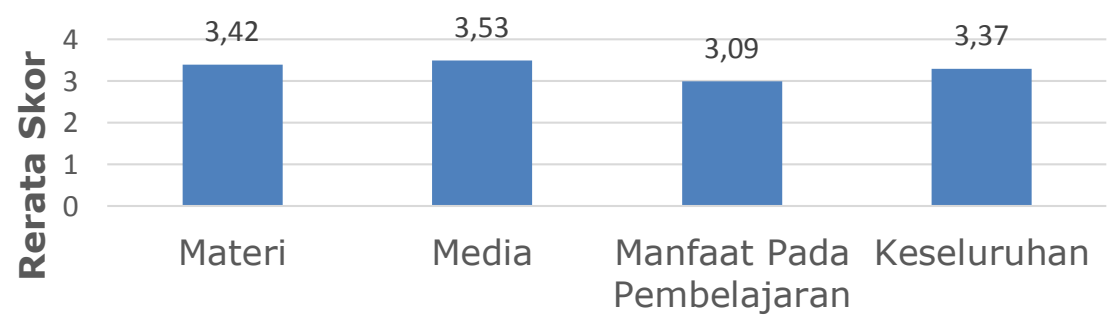

Aspek Penilaian

\section{Gambar 3. Hasil Uji Skala Kecil Pada Peserta Didik}




\title{
Hasil Uji Skala Besar
}

Hasil uji skala besar produk pada 32 peserta didik menunjukkan rata-rata skor sebesar 3,36 dengan memperoleh kriteria sangat layak. Hasil respons peserta didik tahap uji coba lapangan ditunjukkan pada Gambar 4.

UJI SKALA BESAR PADA PESERTA DIDIK

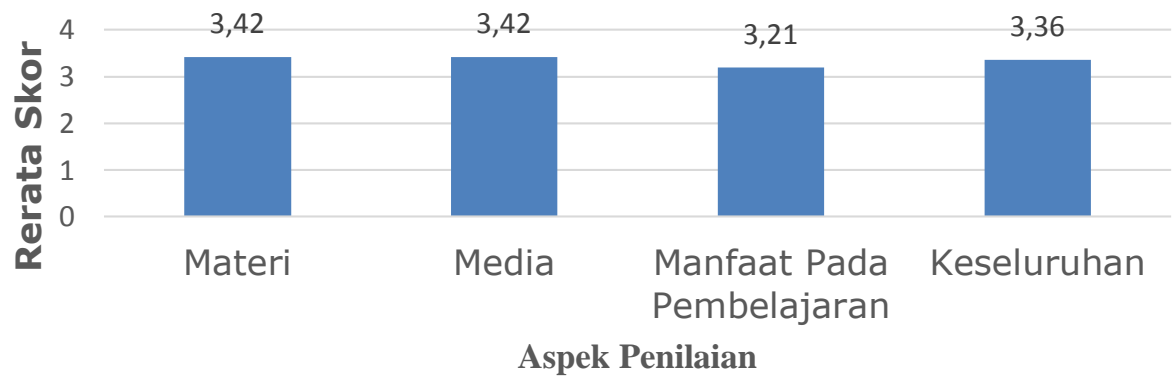

Gambar 4. Hasil Uji Skala Besar Pada Peserta Didik

\author{
PEMBAHASAN \\ Pengembangan Komik
}

Hasil observasi menunjukkan bahwa media komik berbasis Science Edutainment tersebut terlihat mampu menarik minat peserta didik dalam membaca media tersebut. Pembelajaran menggunakan media komik yang kombinasikan dengan Science Edutainment akan menekankan pada kegiatan bermain yang merupakan sifat alamiah anak. Menurut Indriati (2012) pembelajaran Science Edutainment merupakan cara belajar dengan kondisi suasana yang menyenangkan dan sesuai tujuan pembelajaran serta dapat memunculkan daya tarik peserta didik. Peserta didik yang tertarik pada sumber belajar merupakan awal terjadinya peningkatan prestasi belajar peserta didik. Peserta didik tidak akan mengalami kebosanan dalam proses belajar karena adanya konsep bermain sambil belajar dengan pembentukan kelompok-kelompok kecil dalam proses pembelajaran.

Komik Sains yaitu sebuah media pembelajaran yang berfungsi sebagai alat penyebar informasi bagi peserta didik. Menurut Emda (2011) bahwa pemilihan media harus sesuai dengan konsep dan dapat berkontribusi dalam proses belajar mengajar. Minat belajar peserta didik dan pengalaman belajarnya akan tumbuh dengan sendirinya jika media yang digunakan dipilih dengan tepat sebagai alat bantu pengajaran (Silalahi, 2015).

Media komik berbasis Science Edutainment yang dikembangkan di sini dapat dijadikan sebagai sumber belajar peserta didik selain buku paket atau LKS. Komik lebih menarik dan disukai peserta didik karena di dalamnya terdapat banyak gambar yang bervariasi. Dengan menggunakan media komik berbasis Science Edutainment diharapkan bisa mengaktifkan fisik dan mental peserta didik. Kemampuan membaca peserta didik dapat dikembangkan dengan gambar visual komik yang akan meningkatkan membaca secara komperhensif (Ali, 2013).

Peserta didik akan mudah mengingat informasi yang disampaikan dengan rutin membaca. Trihendradi (2014) Tidak semua informasi yang kita dapatkan akan diingat dalam waktu yang lama, akan tetapi informasi itu bisa diingat dalam jangka panjang jika diperhatikan dan diulang terus-menerus. Dengan menggunakan gambar/visualisasi akan membantu mengingat dan menyimpan informasi secara baik. Penggunaan komik berbasis Science Edutainment pada mata pelajaran IPA diharapkan bisa menjadi sarana untuk mengingat materi-materi yang telah di sampaikan.

Ketika dilakukan tahap penyebarluasan media komik tampak peserta didik melakukan diskusi dengan temannya. Kondisi ruang kelas menjadi lebih terlihat menyenangkan dibandingkan sebelumnya. Beberapa peserta didik menirukan dialog percakapan tokoh yang ada di dalam komik tersebut. Suasana kelas juga cukup 
kondusif dan peserta didik terlihat mulai berminat untuk mempelajari materi yang ada dalam komik berbasis Science Edutainment. Setelah penyebarluasan media komik tersebut, media komik yang dikembangkan tidak ada proses revisi. Hal ini dikarenakan Selama proses pembelajaran tidak ditemukan kendala yang mengharuskan untuk melakukan revisi. Hal tersebut sesuai dengan pendapat Sugiyono (2010) yang menyatakan bahwa apabila terdapat kekurangan dan kelemahan maka dilakukan revisi produk.

Bertambahnya minat baca, daya ingat, dan kemampuan berpikir peserta didik bisa ditumbuhkan melalui sifat dari komik itu sendiri yang menarik untuk dibaca. Peserta didik pada jenjang SMP dengan rata-rata usia mereka adalah remaja sehingga memiliki sifat penolakan terhadap sesuatu lebih besar. Kemunduran kecerdasan kognitif setiap peserta didik terjadi karena tidak sesuainya penerimaan pengalaman belajar. Sehingga untuk mengatasi permasalahan tersebut, guru harus memberikan rangsangan yang menarik seperti komik sains agar dapat mendorong kemampuan berpikir peserta didik (Hastuti, dkk., 2014).

\section{Hasil Sikap Literasi Sains Peserta didik}

Kuesioner sikap literasi sains diberikan pada peserta didik sebelum dan sesudah pembelajaran. Tujuan pemberian kuesioner ini yaitu untuk mengetahui ada atau tidaknya peningkatan sikap literasi sains peserta didik sebelum dan sesudah perlakuan. Hasil kuesioner sikap literasi sains dan uji $n$-gain score ditunjukkan pada Tabel 3.

Tabel 3. Hasil kuesioner sikap literasi sains

\begin{tabular}{cccc}
\hline Bidang Sikap & Pretest & Posttest & N-Gain Score \\
\hline Minat sains & 70,11 & 85,74 & 0,52 \\
\hline Menilai pendekatan ilmiah & 67,87 & 84,32 & 0,51 \\
\hline Kesadaran lingkungan & 65,16 & 85,86 & 0,59 \\
\hline
\end{tabular}

Setelah perlakuan dilakukan, antara nilai pretest dan posttest kuesioner sikap literasi sains menunjukkan adanya perubahan hasil. Hal tersebut dilihat dari hasil pretest menunjukkan bahwa pada bidang minat sains nilai pretest yang diperoleh yaitu sebesar 70,11 dan nilai posttest sebesar 85,74 . Sehingga hasil $N$-Gain Score pada bidang minat sains sebesar 0,52 yang termasuk kriteria sedang. Pada bidang menilai pendekatan ilmiah nilai pretest yang diperoleh yaitu sebesar 67,87 dan nilai posttest sebesar 84,32. Sehingga hasil $N$-Gain Score pada bidang menilai pendekatan ilmiah sebesar 0,51 yang termasuk kriteria sedang. Pada bidang kesadaran lingkungan nilai pretest yang diperoleh yaitu sebesar 65,16 dan nilai posttest sebesar 85,86 . Sehingga hasil $N$-Gain Score pada bidang kesadaran lingkungan sebesar 0,59 yang termasuk kriteria sedang. Dari hasil tersebut dapat diketahui hasil $\mathrm{N}$-Gain Score yang paling kecil yaitu pada bidang minat sains. Sedangkan hasil $\mathrm{N}$-Gain Score yang paling besar yaitu pada bidang kesadaran lingkungan. Menurut Hake (1999) perolehan rata-rata skor pada penilaian termasuk dalam kriteria "sedang". Berdasarkan hasil tersebut, bahwa penerapan media komik berbasis Science Edutainment yang dilakukan sudah cukup efektif. Hal tersebut dapat dilihat dengan adanya peningkatan kemampuan literasi sains peserta didik pada aspek sikap.

Pada saat memulai kegiatan pembelajaran guru memberikan contoh permasalahan lingkungan untuk menumbuhkan Kemampuan literasi sains peserta didik pada aspek sikap. Dalam memunculkan sikap peserta didik digunakan sebuah permasalahan dalam pembelajaran untuk menarik minat peserta didik (Sanjaya, 2014). Dari pernyataan tersebut diharapkan memunculkan rasa ingin tahu dan memotivasi peserta didik dalam pemecahan suatu masalah. Dengan begitu, akan muncul perkembangan sikap tertarik peserta didik terhadap sains.

Peserta didik menganalisis permasalahan lingkungan yang disajikan untuk memecahkan masalah lingkungan tersebut. Kegiatan ini dapat menumbuhkan sikap 
sains peserta didik pada inquiry sains, kegiatan menganalisis, kecakapan peserta didik akan berkembang, memilah dan mengumpulkan data, memetakan dan menyajikan hasil yang mudah untuk dipahami. Menurut Toharudin, dkk., (2011) bahwa tujuan dari kegiatan pembelajaran sains yaitu untuk menguasai konsep-konsep sains yang aplikatif dan bermakna bagi peserta didik. Sehingga komik berbasis Science Edutainment bisa dijadikan media untuk mencapai tujuan pembelajaran sains dalam kegiatan pembelajaran.

Menurut Hartati (2016), tahap menganalisis dan mengevaluasi proses pemecahan masalah sikap pada akhir pelajaran akan menumbuhkan literasi sains. Guru menguatkan konsep dan mengaitkan hasil pemecahan masalah dengan kondisi lingkungan yang ada di sekitar pada saat proses evaluasi berlangsung. Guru akan mencoba mulai dari hal kecil untuk menumbuhkan kesadaran terkait bahaya pencemaran lingkungan seperti membuang sampah pada tempatnya. setelah kegiatan ini, peserta didik diharapkan dapat memiliki tanggung jawab untuk melestarikan alam di sekitarnya.

\section{KESIMPULAN}

Simpulan dari penelitian ini adalah sebagai berikut.

1. Pengembangan komik berbasis Science Edutainment dapat dilakukan dengan mengikuti metode $R \& D$ (Research and Development) dengan model 4-D menurut Thiagarajan (1974) yang meliputi 4 tahap pengembangan yaitu Define (pendefinisian), Design (perancangan), Develop (pengembangan), dan Disseminate (penyebarluasan).

2. Hasil $N$-Gain Score pada bidang minat sains sebesar 0,52 yang termasuk kriteria sedang. Hasil $\mathrm{N}$-Gain Score pada bidang menilai pendekatan ilmiah sebesar 0,51 yang termasuk kriteria sedang. Hasil $\mathrm{N}$-Gain Score pada bidang kesadaran lingkungan sebesar 0,59 yang termasuk kriteria sedang. Hasil tersebut menunjukkan bahwa penerapan media komik berbasis Science Edutainment yang dilakukan dapat meningkatkan kemampuan sikap literasi sains peserta didik sehingga bisa dikatakan sudah cukup efektif.

\section{SARAN}

1. Komik dapat dibuat dalam bentuk komik digital, sehingga dalam pembuatannya memerlukan biaya yang lebih murah, serta komik tersebut dapat lebih mudah digunakan di segala kondisi.

2. Tema materi komik bisa diganti dengan materi-materi yang lain.

\section{DAFTAR PUSTAKA}

Aisyah, N., Bayu Widiyanto, M. Aji Fatkhurrohman. (2018) 'Efektivitas Penggunaan Alat Peraga Sistem Peredaran Darah terhadap Hasil Belajar Peserta Didik Kelas VII SMP N 12 Kota Tegal', Jurnal Pendidikan MIPA Pancasakti, 2(1), pp. 61-67.

Ali, A. (2013) 'The effect of comic strips on efl reading comprehension', International Journal on New Trends in Education and Their Implication 4 (5), pp. 54-64.

Budiharto, W. (2014) 'Teori dan Implementasi (Edisi Revi)', Yogyakarta: Penerbit Andi.

Daryanto. (2015) 'Media Pembelajaran', Bandung: PT Sarana Tutorial Nurani Sejahtera.

Emda, A. (2011) 'Pemanfaatan Media Dalam Pembelajaran Biologi di Sekolah', Jurnal Ilmiah Didaktika, 12 (1).

Evelyn, F., \& Wahyu Septiana, Wan Syafi'i, D. (2015) 'Pengembangan Komik Sebagai 
Media Pembelajaran IPA Kelas VII SMP pada Materi Pokok Interaksi Makhluk Hidup

dan Lingkungan', Jurnal Pendidikan IPA Indonesia, pp. 1-12.

Hake, R. R. (1999) 'Analyzing Change/ Gain Score', American Educational Research Methodology.

Hartati, R. (2016) 'Peningkatan Aspek Sikap Literasi Sains Siswa SMP Melalui Penerapan Model Problem Based Learning pada Pembelajaran IPA Terpadu', EDUSAINS, 8(1), pp. 90-97.

Haryanti, Novita. Muriani Nur Hayati, M. Aji Fatkhurrohman. (2018) 'Keefektifan Penggunaan Alat Peraga Sistem Peredaran Darah dalam Pembelajaran IPA Kelas VIII MTs Negeri Pemalang', Jurnal Pendidikan MIPA Pancasakti, 2(1), pp. 34-37.

Hastuti, A.A, Dewi Mustikaningtyas, dan Arif Widiyatmoko. (2014) 'Pengembangan LKS Berbasis Education Game Pada Tema Rokok dan Kesehatan', Jurnal Unnes Science Education, 3 (3)

Indriati, D. S. C. P. (2012) 'Meningkatkan Hasil Belajar IPA Konsep Cahaya Melalui Pembelajaran Science-Edutainment Berbantuan Media Animasi', 1(2), pp. 192197.

Mardapi, Djemari. (2008) 'Teknik Penyusunan Instrumen Tes dan Nontes', Jakarta: Alfabeta.

Muhafid, Ervian Arif. (2013) 'Pengembangan Modul IPA Terpadu Berpendakatan Keterampilan Proses pada Tema Bunyi di SMP Kelas VIII. Skripsi. Semarang: Program Sarjana Fakultas Matematika dan Ilmu Pengetahuan Alam Universitas Negeri Semarang,

Kharizmi, M. (2015) 'Kesulitan Siswa Sekolah Dasar Dalam Meningkatkan Kemampuan Literasi', JUPENDAS, 2(2), pp. 11-21.

Muhson, Ali. (2010) 'Pengembangan Media Pembelajaran Berbasis Teknologi Informasi', Jurnal Pendidikan Akuntansi Indonesia, VIII(2), pp. 1-10.

Nur Hayati, Muriani. Saptorini, T. W. S. (2016) 'Penggunaan Discrepant Events Dengan Pendekatan Poe Terhadap Hasil Belajar Kelarutan dan Hasil Kali Kelarutan Peserta Didik', Pancasakti Science Education Journal, 1(1), pp. 35-41.

OECD. (2016) 'PISA 2015 results' (Volume I): Excellence and equity in education

Pardimin and Adi Widodo, S. (2017) 'Development Comic Based Problem Solving in Geometry', International Electronic Journal of Mathematics Education, 12(3), pp. 233-241.

Purwanto, D. (2013) 'Pengembangan Media Komik Ipa Terpadu Tema Pencemaran Air', Jurnal Pendidikan Sains E-Pensa, 01(01), pp. 71-76.

Sanjaya, Wina. (2014) 'Strategi Pembelajaran', Jakarta: Kencana Prenada Media Group.

Saputro, Anip Dwi. (2015) 'Aplikasi Komik Sebagai Media Pembelajaran', Staf Pengajar Fakultas Agama Islam Unmuh Ponorogo. 
Silalahi, D.W. (2015) 'Penggunaan Media Komik Dalam Pembelajaran Biologi Untuk Meningkat Hasil Belajar Kognitif dan Afektif Peserta Didik Kelas VII', Prosiding Seminar Nasional Biologi Universitas Muhammadiyah Malang.

Sudjana , N, dan Ahmad Rivai. (2015) 'Media pengajaran', Bandung: Sinar Baru Algensindo.

Sugiyono. (2010) 'Metode Penelitian Kuantitatif, Kualitatif, Dan R\&D', Bandung: CV. Alfabeta.

Thiagarajan. (1974) 'Thiagarajan, Sivasailam; And Others Instructional Development for Training Teachers of Exceptional Children: A Sourcebook. Indiana Univ., Bloomington. Center for Innovation in', Research and Development, (Mc), pp. 137-159.

Toharudin, U., Hendrawati, S., \& Rustaman, A. (2011) 'Membangun Literasi Sains Peserta Didik', Bandung: Humaniora.

Trihendradi. (2014) 'Mengasah Memori Anak', Yogyakarta: ANDI.

Zhasda, J. and Sumarmin, R. (2018) 'Analysis of Biological Science Literacy a Program for International Student Assessment ( PISA ) Class IX Junior High School Students at Solok Town', International Journal of Progressive Sciences and Technologies (IJPSAT), 6(2), pp. 402-410. 